\title{
Labeling, Not Otherwise Specified
}

National Cancer Institute

\section{Source}

National Cancer Institute. Labeling, Not Otherwise Specified. NCI Thesaurus. Code

C113017.

Any labeling operation not elsewhere described. 